\title{
Serbia's Prime Minister Election in Western and Serbian Press: Progress on Gay Rights or a Decoy Move
}

\author{
Milena Škobo \\ Assistant Professor, PhD \\ Faculty of Philology, Anglistics, Sinergija University, Republic of Srpska
}

\begin{abstract}
The news that Ana Brnabić became the first Serbian gay female prime minister in 2017 triggered various questions concerning Serbia's attitude towards LGBT population in Western media. Serbia is seen as a patriarchal country and it is noted that many attempts to organize a Pride Parade without violent demonstrations have been in vain, i.e. 2010 Pride Parade ended in violence with 150 injured people. The aim of this paper is to examine whether the election of Ana Brnabic for the first gay PM in the region has led to a better positioning of Serbia in the global world and whether this appointment improved the image of Serbia in the Western media. For the purpose of this analysis American and British press (the Washington Post, the New York Times, the Guardian, and the Independent) as well as Serbian leading pro-government and anti-government newspapers (Blic, Vreme, Informer and Danas) have been used as a reference point.
\end{abstract}

Keywords Western Media, Newspapers, Serbia, LGBT population

\section{Introduction}

What does Serbia do to ensure respect for LGBT rights? What sort of message does it send to the world by selecting Brnabic for its first openly gay PM? What do the LGBT communities in Serbia expect to be done regarding their legal status? How does traditional and conservative Serbia perceieve Vučić's decision to appoint Brnabić? What is the opinion of the Western and Serbian press about this selection? How does it affect public opinion in both Serbia and the global world? These are the most challenging questions addressed in this paper.

The first part of the paper provides a legal framework regarding the status of LGBT population in Serbia and the most recent modifications and changes in the legal system of Serbia concerning the rights of the minority groups. It stresses out the key issues Serbia still needs to deal with in order to provide equal rights for the minority groups. The second part of the paper deals with the corpus that consists of two parts: the analysis of 8 selected articles reporting on Brnabićs appointment in the most prominent British and American newspapers and the analysis of 8 selected articles dealing with the same issues in Serbian leading pro-government and antigovernment newspapers. Final section of the paper summarizes both parts by offering broader perspective from which the country has to address this issue.

\section{Legal framework regarding LGBT population in Serbia}

By 2009 the Serbian Parliament adopted four laws, which specifically ban discrimination based on sexual orientation: the Labour Law, the Law on Higher Education, and two media laws - the Law on Public Information and the Law on Broadcasting.

In March 2009, the Serbian Parliament adopted a comprehensive Anti-Discrimination Law. Article 21 of the law specifically bans discrimination based on sexual orientation and allows the right to privacy, as well as free expression of sexual orientation. Article 387 of the Serbian Criminal Code provides a framework for prosecuting those who threaten organisations and individuals due to their commitment to the "equality of people". In July 2011, Parliament adopted a Youth Law, prohibiting discrimination on the grounds of sexual orientation. In the same year Parliament approved a change in Health Insurance Law, based on which sex change surgeries will be fully subsidised by the State, beginning in 2012. Also, in December 2012, the Serbian Parliament approved changes to the Criminal Code to introduce the concept of "hate crime", on the basis of sexual orientation and gender identity". While the AntiDiscrimination Law clearly reflects a marked improvement in the legal status of LGBT individuals, it has been criticized for allowing 
overly-broad exceptions and the government has been slow in implementing the law and responding to complaints, i.e. the law condones discriminatory attitudes from religious leaders.

In 2014, Serbia adopted a strategy (2014-2018) to combat discrimination against LGBT people which was followed in 2015 by the adoptions of a National Action Plan (NAP). Although the NAP has been considered as a step forward by LGBT groups, the poor practical implementation of legislation seems to be the biggest drawback. Namely, there are many cases of violence, insults, belittling and discrimination against the LGBT persons that are not documented or reported by the media.

LGBT people continue to face harassment and discrimination in Serbia. Although homosexuality is no longer classified under "sexual deviations and disorders", many people in Serbia still consider it an illness. The LGBT community is one of the most marginalized social groups in Serbia since it still faces life in invisibility, uncertainty and fear (Mršević 2015: 295). There are no national statistic reports on cases of discrimination and violence based on sexual orientation and gender identity and the NGOs' reports are basically the only source of such information (Mršević 2015: 295-296).

In May 2014, Amnesty International identified Serbia as a country with a marked lack of will to tackle homophobia and transphobia, noting that public authorities had repeatedly banned pride marches on the basis of violent threats from homophobic groups, i.e. in 2011, Serbia banned Belgrade Pride Parade for fear it would end in violence as the one in 2010, when thousands of far-right groups tried to stop the parade by participating in clashes with the police. It was not until 2014 that pride parades have started to be successfully held every year, with local mayors and some government ministers regularly attending.

As of 2016, Article 62 of the Serbian Constitution defines marriage as a union between a man and a woman whereas the 2000 Constitution did not mention gender in Article 29 of its marriage provision. Also, no law has been passed in Parliament regarding registered partnership for same-sex couples despite the fact that political discussions concerning this issue have started in 2015. Civil partnerships and same-sex marriage are not recognized, while joint adoption and second parent adoption as well as family planning are not allowed.

According to a 2017 poll carried out by ILGA, $59 \%$ of Serbians agreed that gay, lesbian and bisexual people should enjoy the same rights as straight people, while $24 \%$ disagreed. Additionally, $64 \%$ agreed that they should be protected from workplace discrimination. $21 \%$ said that people in same-sex relationships should be charged as criminals, while 55\% disagreed. As for transgender people, 63\% agreed that they should have the same rights, $65 \%$ believed they should be protected from employment discrimination and $51 \%$ believed they should be allowed to change their legal gender.

In 2019, the association ILGA-Europe ranked Serbia 30th in terms of LGBT rights out of 49 observed European countries.

\section{British and American Press}

Valerie Hopkins, a freelance journalist working in the Balkans, reported for the Washington Post that the selection of Ana Brnabic for the first gay prime minister was "just for show", that is to say, Aleksandar Vučić made this selection in order to "boost [his] popularity with voters" and to convince Brussels that he was "a trustworthy liberal democrat who respects diversity and values tolerance" (Hopkins 2017). After referring to Serbia as "a socially conservative country", Ms Hopkins recalls that Aleksandar Vučić and former Prime Minister Ivica Dačić have made many "homophobic comments" and that in recent years Pride Parades in Serbia have been "highly militarized, with some 5,000 policemen protecting the route"(Hopkins 2017). It is further stated that many in the ruling coalition complained about the selection of Brnabić because of her sexual orientation and that "some observers" believe that "Serbia is trying to reassure the West that it supports European values while masking a trend of rising authoritarianism" (Hopkins 2017). The article then touches upon Vučićs quite ceremonial inauguration, while his political party is compared to the funeral of Marshall Broz Tito. It is also stated that tradition of balancing between East and West is popular with both the Serbian public and Aleksandar Vučić. The article ends by referring to the text in a Serbian lifestyle website that ironically lists " 42 things that will change in Serbia with 
a gay PM. Next to each number in the listicle is an empty space, except for number 42 , which simply says 'NOTHING'" (Hopkins 2017).

Another article in the Washington Post entitled "Conservative Serbia just chose a gay woman for prime minister" deals with Ana Brnabić Serbia's first female and first openly gay head of government. The article depicts Serbia as a country that is "not known for its gay-friendly policies" relying on the statements of many conservative Serbian politicians who object her selection (i.e. the Dveri group, a nationalist official Dragan Marković Palma), the statement of Serbian Orthodox Bishop Amfilohije Radović from 2009 who compared Pride Parades to "Sodom and Gomorrah" and a 2010 survey that showed that "14 percent of Serbians believe[d] that violence and beatings [were] legitimate way to respond to homosexuality" (Erickson 2017). It is stated in the article that the president's selection of Brnabić is seen by many as his effort to pave the country's way to its EU admission as soon as 2020 as well as to ensure his power (Erickson 2017). In its final analysis the article relies on the opinion of Boban Stojanović, a political scientist at the University of Belgrade, who claims that foreign policy will definitely remain the domain of Vučić since Brnabić has "little political experience and no real base of power" (Erickson 2017).

The Guardian examines the selection of Brnabić in the context of "virulent homophobia [that is] still widespread in the Balkans" (MacDowall 2017). It quotes the statement of Goran Miletić, a civil rights activist and Belgrade Pride Organizer, who says that the selection of gay woman could only send a positive message to the world, although he is of opinion that respect for LGBT rights is unlikely to grow in near future. It is further stated that Belgrade's Pride Parade "has been suspended in the past over 'security concerns' and now takes place under heavy police guard, amid protests by the far right and the Orthodox Church" (MacDowall 2017). The Guardian also mentions the fact that Mr. Vučić is accused by his critics of controlling the media and turning a blind eye to corruption in his close circles (MacDowall 2017). It is also stated that Vučić's choice of Brnabic will help him maintain his power over all areas of policy due to her relatively low profile and political inexperience. The article ends with the statement of Boban Stojanović who believes that the selection of Brnabic will "mask a real picture of the situation of civil and human rights in Serbia" (MacDowall 2017).

In an interview with the Guardian Ana Brnabić expressed her disapproval of being branded Serbia's gay PM (Wintour 2017). Brnabić is portrayed as an educated person who is "smart, pragmatic and agile" thus able to transform the image of Serbia and present the country in a more positive light. She said for the Guardian that Serbia was not a homophobic country, that there were different attitudes concerning this question and that Serbian people "had right not to be portrayed by loud minority" (Wintour 2017). Despite the fact that Brnabić is portrayed as a person who may "fail to change Serbia" her selection is still characterized as "an experiment worth watching" (Wintour 2017).

The Independent reports on the selection of Brnabic in the context of divided reactions on her nomination (Surk 2017). It is stated that although "the Western officials may have seen the nomination as a sign of progress", some "deeply conservative" politicians called it a "part of a degenerate Western plot" (Surk 2017). On the other hand, critics on the left and some minority groups (lesbian, gay, bisexual, and transgender) in Serbia dismiss her as Vučić's puppet and express their concern that her sexual orientation will be used as a powerful means for stifling the independent media and masking human rights abuses. It is mentioned in the article that many people believe that Brnabić's sexual orientation alone "disqualified her from leading a government" (Surk 2017) bearing in mind the fact that Serbia is perceievd as a patriarchal society where majority of people consider homosexuality an illness. It is interesting to mention that some critics claimed that she was "forced on Vučić by the West to boost Serbia's chances of joining the EU" (Surk 2017). Both Brnabić and Vučićs responses to these reactions are objectively reported. Brnabić strictly refuses to be defined by her identity and sexual orientation and has made clear she is not an activist. The article ends with the statement of Zoe Gudović, a social justice activist in Serbia, who is skeptical of Brnabić's political engagement and expresses her concerns regarding Brnabić becoming an integral part of the country's nationalist and authoritarian regime. 
Another article published in the Independent reports on Brnabic attending the Pride march in Belgrade in 2017. It is acknowledged that the atmosphere during 2017 Pride Parade has been more relaxed and that gay activists have hailed Brnabić's appointment but that "homophobia is still widespread in Serbia" (Radovanovic 2017). Also, it is stated that the head of the Serbian Orthodox Church has compared homosexuality with incest and that gay activists in Serbia are of opinion that there is still much more to be done regarding diversity and respect of rights for all the citizens in Serbia.

According to the article entited "Progress on Gay Rights in Serbia, with a Catch" published in the New York Times, Serbia has a "progressive track record on gay rights". The nomination of Brnabic is interpreted in the context of Mr. Vučić's political ambitions. Namely, it is stated that there were deep suspicions that he installed "a puppet" as PM in order to increase his power. The New York Times also relies on the 2012 CeSID poll that indicated that almost half of the people believed homosexuality was an illness and the statements of some pro-Russian politicians who saw the nomination as part of a Western plot (i.e. the statement of Dragan Marković Palma, the chief of the United Serbia Party, who declared that Ana Brnabić was not his PM). It is clearly stated in the article that Serbia would send a powerful signal to the rest of the world by presenting itself as a country able to "move beyond old prejudices" only if Brnabić did not become a "tool of an autocrat, or discarded to further Mr. Vučić's sweeping political ambitions".

Another article in the New York Times expresses the same concerns and suspicions concerning Brnabićs selection for the first gay PM relying on the same sources used in the above mentioned magazine. The article also provides Ms. Brnabić's reply on the accusations that she was a mere Vučić's puppet, as well as her response to the attacks on her sexuality and gender. It is further stated that only Western officials may have seen her nomination as a sign of progress in Serbia, while all the rest (nationalists, opposition liberals, some members of the president's governing party) disapprove of the selection. The magazine stresses that, among other things, Ms. Brnabić's sexual orientation alone is very likely to disqualify her from leading
Serbia that is described as "a deeply conservative, relatively poor Balkan country". It is also said that any enthusiasm among her supporters dampened after she proposed a list of cabinet ministers (i.e. a former labour minister Aleksandar Vulin as a defense minister in 2017 and a former controversial Belgrade Mayor Siniša Mali as a financial minister in 2018). Aleksandar Vučić is believed to be behind these nominations.

However, there are some Western magazines that published interviews conducted with Aleksandar Vučić and Ana Brnabić, where the issues observed were tackled from a different perspective, thus depicting Serbia and its efforts to join the EU in a favourable light. Namely, the Economist broadcast a 26-minutelong interview with Serbian PM, where she tried to address all the issues regarding her appointment adequately and stress out Serbia's progress in many fields, especially those concerning its economic growth, investments and better positioning in the global world market.

\section{Serbian Press}

In one of its articles concerning Brnabić's appointment, a Serbian newspaper Blic explains why Ana Brnabić is a good candidate for the Prime Minister. This article also explores the following questions: what kind of message does Serbia send to the world by Brnabic's appointment; what are the expectations of the LGBT population now and how is traditional and conservative Serbia going to deal with the selection of Brnabić for the PM?

It is stated in the article that Brnabic's sexual orientation has put aside all of her qualifications (Mastilović Jasnić 2017). Conservative part of Serbian society has difficulties to accept Vučić's decision, i.e. it has been previously mentioned that Dragan Marinković Palma stated that Ana Brnabić was not his Prime Minister and Vučić's opposition called Brnabić 'homo $\mathrm{PM}^{\prime}$ and 'bipolitician'. LGBT activists hail the selection of Brnabic and hope that the new draft law on gender equality will be adopted during Brnabić's mandate but are unsure whether the status of LGBT groups will be the priority of the new government. The political analysts and experts' opinions regarding the decision to select the first openly gay woman for the PM are divided. The article relies on the opinions 
of Ivan Stanković, the founder and director of PR agency "Komunis" and Cvijetin Milivojević, the owner of PR agency "Pragma". Stanković believes the image of Serbia in the international environment will be improved, while Milivojević claims that having a good international PR cannot be the utmost reason for the selection of Brnabic (Mastilović Jasnić 2017). The article ends with Ana Brnabićs statement that being lesbian is not her personality trait or a part of her Curriculum Vitae and expresses hope that people would support or oppose her for what she does.

In the article entitled "Ana Brnabić, the politics of symbols" published in the antigovernment newspaper Vreme, the author comments on Brnabić's appointment in the light of current political climate in Serbia. Namely, he believes that selecting Brnabić for PM "sounds great" and it might be defined as "a step ahead" only from the perspective of those living outside Serbia (Pančić 2017). The author of the article believes that the selection of a gay female for PM in a country that is "a legalized personal ownership of one man" and where "institutions are in ruins, and political system a caricature of what it is supposed to be", can be compared to "a rocket that burns before it is launched" (Pančić 2017).

In another article published in Vreme, the author comments on Vučić's "pompeous and spectaculous" inauaguration, comparing his speech to Slobodan Milošević'statement "If we cannot do business, we can fight" (Turudić 2017). He expresses little hopes that Vučić's mandate is time for change in Serbia and believes that Ana Brnabićs appointment boils down to "much ado about nothing", since she is about to become a Vučić's ventriloquist, thus with little possibility to act independently.

Another article published in Vreme deals with Brnabić's statements about Serbia choosing EU over Russia given during an interview for the American agency "Bloomberg". The author of the article compares Brnabić to Alice in Wonderland - "she is a foreign body not only in the government but also in the political system, where she is perceived by many as someone who entered their world though uninvited" (Anastasijević 2017). Another article published in the same newspapers deals with Brnabić's numerous "faults": apart from "Bloomberg interview affair", she is branded as a woman who is silent when it comes to violence against women; she is someone who gives priority to digitalization of public administration instead of respecting basic human rights; she is perceived as a person who knows little about executive and legislative power; above all, she is defined as someone who advocates "national symbol cults", i.e. she stated that there was nothing wrong in putting Aleksandar Vučić's portrait in the public institutions (Gligorijević 2017).

One of the articles published in daily newspapaper Informer sheds positive light on the selection of Brnabić for Serbian PM. Namely, it is written in the article that the analysts agree that the selection of Brnabic for PM is the best decision. The article relies on the opinion of Bojan Klačar, an executive director of CESID, and Vladimir Vuletić, a sociologist. According to Klačar, Brnabić's appointment is important since her name is not associated with the affairs and scandals from the past and it is the first time in the history of Serbia that a female has taken the role of PM. Above all, she is a member of the minority group as being openly gay and does not belong to any political party. Vuletić believes Vučić's choice of Brnabić has sent a positive image of Serbia to the world and expects that she will justify confidence reposed in her.

Another article published in the Informer hails Vučić's decision to appoint Brnabić. It deals with a detailed presentation of Vučićs arguments for selecting Brnabić and the opinion of political analysts such as Dragan Anđelković, Branko Radun and Dejan Vuk Stanković who justify Vučić's decision. Namely, Anđelković praises Brnabić's experience regarding international funds and cooperation with foreign institutions and describes her as a tolerant person willing to cooperate, which makes her fit for working with ministers. According to Anđelković, Brnabićs lack of political experience is her only drawback. Radun believes Vučićs decision is triggered by the fact that the president wanted to achieve balance within his own party, while Stanković points out Brnabić's competence, uncoruptness and readiness to dedicate her attention to implementing economic reforms. Stanković adds that Brnabić's appointment is symbolic 
due to the fact that she is a female, a non-party and an LGBT member.

In an article written by 'BBC news in Serbian' and published in a daily newspaper Danas, it is stated that LGBT population in Serbia still faces discrimination although there are some positive aspects regarding its conditions. The article is written from the point of view of a gay person living in Serbia who states that the country's support of Pride Parade is not genuine. Namely, he is of opinion that Serbia does not put enough effort in trying to improve the status of LGBT and other minority groups. The article also relies on the opinions of Dragana Todorović and Vuk Raičević from the organization 'Equal Rights Association' (ERA) who agree that the position of LGBT groups in the region is generally bad and that discrimination against minority groups is widely spread, especially in the exYugoslav countries. Goran Miletić, a civil rights activist and Belgrade Pride organizer, notes that despite the fact that the improvements regarding the treatment of LGBT groups in Serbia are visible (the first openly gay and female PM, lesbian couples participating in reality shows, gay activists' engagement, etc.), there are still no changes in respect of law regulating the status of LGBT people. Predrag Azdejković, the president of lesbian info center, says for the newspaper that Belgrade Pride Parade is "a fashion show without fashion" since nothing has been done so far regarding the fulfillment of requirements of LGBT activists.

\section{Conclusion}

Relying on the Press Freedom Index report compiled by Reporters Without Borders for the period between 2016 and 2018, there has been a falling trend of media freedom in Serbia (Nikolić 2018: 265). Namely, Serbia is ranked $5^{\text {th }}$ out of 180 countries in $2016,66^{\text {th }}$ in 2017 and $76^{\text {th }}$ in 2018. The most recent data show that Serbia has been ranked 90 $0^{\text {th }}$ in 2019. In the paper entitled "Serbia in British and American media", the author indicates that the most distinquished British and American newspapers depicted Serbia as a country with 'repressive media environment' and 'proVučić tabloids (i.e. the Informer) relying on the statements of some Serbian journalists and reporters who were treated unfairly or who claimed that it was hard to do fair-minded journalism, as well as members of opposition who constantly warned against progovernment media in Serbia (Nikolić 2018: 265). According to the Serbian online magazine "Dnevni Žurnal", the majority of online media in Serbia is not under the government's control. The magazine lists television channels and newspapers with progovernment propaganda activities and those that are not under government's control. Thus, the website Blic is more critically oriented towards the regime than its daily newspaper Blic, while Informer is classified as a clear cut example of a pro-government newspaper. From the analysis of the selected articles it can be deducted that Vreme and Danas are antigovernment newspapers.

The analysis of the selected articles indicated that Serbian pro-government newspapers hail Vučić's decision to select Ana Brnabić for PM and justify his decision by listing all positive things regarding Brnabić, particularly her education, competence, uncoruptness and the fact that she is a female, a non-party member and a member of the minority group. On the other hand, anti-government newspapers comment on Brnabićs election in the light of Vučić's "real" motives for Brnabićs appointment and list Brnabić's "numerous faults" together with her lack of political experience. British and American newspapers predominantly rely on the statements taken from people who do not support Vučić and the government (an interview with Ana Brnabic for the Economist being the exception). Also, some of the articles published in western press suggested that having the first female and openly gay PM should be "an experiment worth watching" and a surprising step ahead for a "socially conservative country" not known for its "gay-friendly policies". Also, some of the articles stress out the fact that what stands behind Brnabić's appointment is Vučić's tactics of ensuring his power by speeding up the process of Serbia's accession to the EU and Serbia's better positioning both in the region and the global world.

In Serbia Brnabićs appointment received criticism from both left-wing and right-wing groups. Right-wing groups oppose her nomination due to her sexual orientation, while left-wing groups believe her sexual orientation might serve as a cover-up for human rights abuses. The opinions of political analysts and experts regarding Brnabićs appointment are also divided. While some 
believe that having a female gay person for PM promotes Serbia and its readiness to adhere to European values, others are of opinion that nothing is going to change due to the fact that she is seen as a Vučić's "puppet". Finally, civil rights and gay activists hail Brnabićs appointment, but claim that Serbia has to do more when it comes to law regulating the status of LGBT people.

The final analysis of the articles selected indicated that the position of LGBT population in Serbia needs to be improved, that legal recognition of same sex partnerhips might be a necessary undertaking and that greater involvement of the country is needed in terms of cutting down homophobia and protecting LGBT people from violence and discrimination.

\section{REFERENCES}

- Anastasijević, Dejan, "Ana Brnabić u zemlji čuda", Vreme, July 15, 2017, https://www.vreme.com/cms/view.php ?id=1515468. Accessed 15 May 2019.

- Erickson, Amanda, "Conservative Serbia just chose a gay woman for prime minister". Washington Post, June 17, 2017. https://www.washingtonpost.com/news /worldviews/wp/2017/06/17/conservati ve-serbia-just-chose-a-gay-female-primeminister/?utm_term $=.908 \mathrm{cc} 128 \mathrm{a} 54 \mathrm{c}$. Accessed 8 September 2018.

- Gligorijević, Jovana, "Šta sve Ana ume sama", Vreme, August 31, 2017, https://www.vreme.com/cms/view.php ?id=1526108. Accessed 15 May 2019.

- Hopkins, Valerie, "A gay woman is Serbia's next prime minister. Was her selection just for show?" Washington Post, June 26, 2017, https://www.washingtonpost.com/news /democracy-post/wp/2017/06/26/a-gaywoman-is-serbias-new-prime-ministerwas-her-selection-just-forshow $/$ ?utm_term $=.60078 \mathrm{~b} 7181 \mathrm{~d} 4$. Accessed 6 March 2018.

- MacDowall, Andrew, "Serbia gets its first female - and gay- prime minister" Guardian, June 15, 2017, https://www.theguardian.com/world/20 17/jun/15/serbia-gains-its-first-femaleand-gay-prime-minister-ana-brnabic. Accessed 22 October 2018.
- Mastilović Jasnić, Ivana. 2017. “GEJ PREMIJERKA Evo zašto je Ana Brnabić dobra za Srbiju". Blic, June 25, 2017, https://www.blic.rs/vesti/politika/gejpremijerka-evo-zasto-je-ana-brnabicdobra-za-srbiju/c2edrh3. Accessed 14 May 2019.

- Mršević, Zorica, "Violence against LGBT persons", in: Dani Arčibalda Rajsa, tom II (ed. Dragana Kolarić), Beograd: Kriminalističko policijska akademija, 2015, 295-303.

- Nikolić, Z. Milena, "Serbia in British and American media", Security, Political and Legal Challenges of the Modern World: conference proceedings, Vol.1/International scientific conference, Bitola, 19-21 October, 2018; (Eds. Svetlana Nikoloska, Angelina Stanojska), Bitola: University "St. Kliment Ohridski", 2018, pp. 258-268.

- Radovanovic, Radul, "Serbia's first openly-gay Prime Minister Ana Brnabic joins hundreds of marchers at LGBT pride event", Independent, September 17, 2017, https://www.independent.co.uk/news/ world/europe/serbia-lgbt-pride-gay-anabrnabic-march-violence-harassmentextremists-belgrade-eu-a7951756.html. Accessed 29 November 2018.

- Reporters Without Borders, 2019 World Press Freedom Index, https://rsf.org/en/ranking/2019. Accessed 15 May 2019.

- Surk, Barbara, "Serbia Gets Its First Female, and Openly Gay, Premier", New York Times, June 28, 2017, https://www.nytimes.com/2017/06/28/ world/europe/serbia-ana-brnabic-primeminister.html. Accessed 29 July 2017.

- Surk, Barbara, "Ana Brnabic: Serbia prepares to welcome first female and openly gay Prime Minister", Independent, June 29, 2017, https://www.independent.co.uk/news/ world/europe/ana-brnabic-serbia-primeminister-first-woman-gay-lesbian-lgbtaleksandar-vucic-a7813951.html. Accessed 13 November 2018.

- Pančić, Teofil, "Ana Brnabić, politika simbola“, Vreme, June 15, 2017, 
https://www.vreme.com/cms/view.php ?id=1506801. Accessed 15 May 2019.

- "Progress on Gay Rights in Serbia, With a Catch", New York Times, June 26, 2017, https://www.nytimes.com/2017/06/26/ opinion/gay-rights-serbia-anabrnabic.html. Accessed 1 July 2017.

- Turudić, Momir, "Nemam autoritet, a nisam ga ni zaslužila", Vreme, June 29, 2017,

https://www.vreme.com/cms/view.php ?id=1512256. Accessed 15 May 2019.

- Wintour, Patrick, "Ana Brnabic: 'I do not want to be branded Serbia's gay $\mathrm{PM}^{\prime \prime}$, Guardian, July 28, 2017, https://www.theguardian.com/world/20 17/jul/28/ana-brnabic-serbia-primeminister-interview. Accessed 18 August 2018.

- "ANALITIČARI SAGLASNI: Izbor Brnabićeve najbolja odluka!" Informer, June 15, 2017, http://informer.rs/vesti/politika/335733 /analiticari-saglasni-izbor-brnabicevenajbolja-odluka. Accessed 15 May 2019.

- An Interview with Ana Brnabić, Economist, https://www.acast.com/theeconomistask $\mathrm{s} /$ theeconomistasks-anabrnabic. Accessed 14 October 2018.

- “BRNABIĆEVA JE DOKAZALA STRUČNOST, IMA SNAGE I ENERGIJE: Analitičari saglasni da je Vučićev izbor premijera odličan za Srbiju!" Informer, June 16 , 2017,

http://informer.rs/vesti/politika/335874

/brnabiceva-dokazala-strucnost-imasnage-energije-analiticari-saglasnivucicev-izbor-premijera-odlican-srbiju. Accessed 15 May 2019.

- BBC news na srpskom, "Srbija: Dva prajda, gej premijerka, a problem isti." Danas, September 14, 2018, https://www.danas.rs/bbc-newsserbian/srbija-dva-prajda-gej-premijerkaa-problemi-isti/. Accessed 20 May 2019.

- "Country Ranking - Rainbow Europe", rainbow-europe.org, https://rainboweurope.org/country-ranking. Accessed 23 May 2019.

- "Homophobia still tolerated by governments around the world", Amnesty
International. 16 May 2014, https://www.amnesty.org/en/latest/ne ws/2014/05/homophobia-still-toleratedgovernments-around-world/. Accessed 23 May 2019.

- https://en.wikipedia.org/wiki/LGBT_rig hts_in_Serbia, accessed 10 May 2019.

- International Lesbian, Gay, Bisexual, Trans and Intersex Association, Minorities Report 2017: attitudes to sexual and gender minorities around the world (Geneva; ILGA, October 2017), https://ilga.org/ilga-riwi-globalattitudes-survey. Accessed 23 May 2019.

- "SERBIA - LGBT Equal Rights Association for Western Balkans and Turkey", https://www.lgbtiera.org/content/serbia. Accessed 23 May 2019.

- https://www.lgbtiera.org/content/serbia

- https://www.lgbtiera.org/content/serbia

- https://www.lgbtiera.org/content/serbia

- In 1997 Serbia started applying ICD-10, the 10th revision of the International Statistical Classification of Diseases and Related Health Problems (ICD), that removed homosexuality from the official list of diseases.

- https://www.amnesty.org/en/latest/ne ws/ 2014/05/homophobia-still-toleratedgovernments-around-world/

- ILGA: The International Lesbian, Gay, Bisexual, Trans and Intersex Association

- https://ilga.org/ilga-riwi-globalattitudes-survey

- https://rainbow-europe.org/countryranking

- https://www.nytimes.com/2017/06/26/ opinion/gay-rights-serbia-anabrnabic.html

- https://www.nytimes.com/2017/06/28/ world/ europe/serbia-ana-brnabic-primeminister.html

- https://www.acast.com/theeconomistask $\mathrm{s} /$ theeconomistasks-anabrnabic

- http://informer.rs/vesti/politika/335733 / analiticari-saglasni-izbor-brnabicevenajbolja-odluka

- http://informer.rs/vesti/politika/335874 / brnabiceva-dokazala-strucnost-ima- 
snage-energije-analiticari-saglasni-

vucicev-izbor-premijera-odlican-srbiju

- https://www.danas.rs/bbc-newsserbian/srbija-dva-prajda-gej-premijerkaa-problemi-isti/
- https://rsf.org/en/ranking/2019

- https://dnevnizurnal.com/ovako-stojestvari-pogledajte-koji-mediji-su-podkontrolom-rezima-a-koji-ne/ 